\title{
The foundation of communication and action in consciousness: Confronting action theory with systems theoretical arguments
}

\author{
FRANK HUYSMANS
}

\section{Abstract}

In action theoretical approaches to the study of mass communication processes, media production and reception activity is interpreted (or 'explained') from the point of view of individual consciousness. The intentionality of the actor is viewed as the starting point for human (social) action. Communication is regarded as a process in which actors intentionally engage to exchange their minds' contents - and is therefore seen as a special case of human action. This view is challenged by Luhmann's social systems theory, which conceives of communication as taking place outside of consciousness. Although communication is a product of the mutual non-transparency of individual consciousnesses, both consciousness and communication should be seen as self-reproducing systems which cannot interfere in each other's operations. According to Luhmann, thoughts cannot be communicated - only communications can be communicated, and thoughts can merely be thought. Actions should be seen as the products of communication, namely of the attribution (be it through communication or through thinking) of social descriptions to systems. Although it may appear to be a fundamental issue, this difference in opinion between action and systems theory can be made productive. In this article, arguments are presented for incorporating Luhmann's view of consciousness and communication as separate, but mutually observing systems into action theoretical approaches.

Keywords: action theory, systems theory, action, communication, consciousness, social action

\section{The individualism of action theory and the collectivism of social theory}

In an essay published in 1985, Jeffrey C. Alexander (1988) describes what he calls the 'individualist dilemma' in phenomenological sociology and symbolic interactionism. Both of these theoretical schools in sociology 
have opted for an individualist instead of a collectivist approach to the problem of social order, i. e., how social order can exist given the fact that people have more or less the same desires, the objects of these desires are scarce and hence cannot be obtained by all. In stressing the individual, creative moment in social action, explaining how social reality can be relatively orderly becomes a problem. In individualist theory, social life must be opened to contingency to such an extent that it, "in the final analysis, makes the understanding of order approximate randomness and complete unpredictability" (Alexander, 1988: 224). Since most theorists of society will not be satisfied with such randomness, Alexander posits that they will incorporate "some aspect of supraindividual pressure or sustenance" (224) in their conceptual schemes. But even in doing so, these theorists are not willing to give up their individualist presuppositions. The collectivist aspect of the theory, however, is not part of the theoretical core; it is just 'attached' to it, and therefore

the collectivist reference will be indeterminate and vague. This indeterminacy and vagueness make it theoretically and empirically frustrating and incomplete. To resolve this problem, obviously, the dilemma itself (i. e., the choice between randomness or residual indeterminacy) must be transcended; this can come about, however, only if the formal adherence to individualism is abandoned (224-225).

The fact that phenomenology and interactionism have not followed that last option is demonstrated in the remainder of Alexander's essay. He goes into considerable detail to show that both traditions have eventually developed radical individualist positions in Harold Garfinkel and Herbert Blumer, respectively. Their followers, Alexander notes, have been caught within the individualist dilemma ever since (254).

Not having read the original essay, one could have the impression that Alexander wished to do away with 'individualist sociology' in favor of the collectivist stance he himself advocates. However, this is not the case, for he makes a clear distinction between the presuppositions in regard to social order on the one hand, and doing empirical research on the other. Whereas he holds that the collectivist perspective is the sole basis for a general framework for social theory, empirical research of interaction between individuals "should incorporate whenever possible the empirical insight of individualistic theories into the concrete operations, structures, and processes of the empirical interactions of concrete individuals" (225). There is, after all, no inherent contradiction between the assertion that only individuals are capable of autonomous actions, and the simultaneous assertion that the results of these actions have 'emergent' properties which cannot be traced back to the intentions of individual actors (Alexander and Giesen, 1987: 20; see also Coleman, 1990). 
This is roughly the perspective I want to advocate here. In both phenomenology and symbolic interactionism, action is said to spring from the individual consciousness of the actor, who interprets his environment (including other actors, human artifacts, social institutions, cultural symbol systems, etc.) and decides to act on the basis of this interpretation. In this perspective, the social environment affects the situation only through the conscious elaboration of the actor(s). Although this may be a useful guiding principle for conducting empirical research, I want to argue that this proposition cannot be held on to if the development of a social theory is what is aimed at. The purpose, however, is not only to elaborate upon Alexander's remarks by showing that it is the stress placed on the actor's individual consciousness in both phenomenology and symbolic interactionism that prevents either approach from being able to conceptualize the 'collective moment' in social action (see the next two sections). Next, I will demonstrate a 'way out' by showing what can be gained for action theory by seriously considering some of Luhmann's remarks about the relationship between consciousness and communication in social life. By distinguishing consciousness and communication as two separate but interdependent systems, the first termed 'psychic system' and the second 'social system', Luhmann offers an alternative perspective that, in my view, deserves being incorporated into action theory. What this means for the study of human action in general and for social action approaches in mass communications research in particular is sketched in the conclusion.

\section{Phenomenological sociology: The foundation of action in the stream of consciousness}

If there is to be a founding father for the phenomenological branch in sociology, it must be Alfred Schütz (1974) with his classic Der sinnhafte Aufbau der sozialen Welt, which was first published in Vienna in 1932. ${ }^{1}$ Schütz sets out to provide Weberian action theory with a phenomenological foundation. He first criticizes Weber for not having properly defined what is meant by the central category Sinn (meaning ${ }^{2}$ ) in his methodology, except that the meaning and the motive for an action appear to be synonymous (Schütz, 1974: 27). Weber (1984) analyzed the interconnectedness of human social actions in terms of means and ends, and posited that social actions can only be explained (in a second instance) after they have been interpreted ('verstanden') by the researcher in terms of the subjective meanings the actor(s) attach to it. In doing so, he instated individual consciousness in theory as the empirical locus of control in human social action. Schütz, referring to the work of the philosopher Edmund Husserl, replaces Weber's means-ends-rationality by a phenom- 
enological analysis of what goes on in the consciousness of the actor while acting. Consciousness directs its attention to itself by synthesizing actual experience with past and future Bewusstseinserlebnisse. This synthesis, Sinnzusammenhang (meaning context), provides the basis for projecting accomplished actions in the future. By visualizing a future state in which this action shall be accomplished, the actor mentally develops a project of his action, which, in Schütz' view, must be seen as the actual Sinn of his action (Schütz, 1974: 126).

In a next step, still firmly founding his analysis on strict Husserlian reasoning, Schütz explains how one consciousness can have access to the Bewusstseinserlebnisse of another. Here, he falls back on 'mundane' experiences of actors living in the 'natural attitude' ( $137 \mathrm{ff}$.; see also Schütz and Luckmann, 1979, 1984). In everyday life, as an actor I only experience segments of another actor's stream of consciousness through my observations of his/her conduct and utterances, since most of the time I subsume my experiences of the other's conduct in objective meaning contexts. That is, I only consider this actor's finished meaning contexts, not the meaning-giving process that has led to them (187 ff.). In order to interpret the other's actions, therefore, I only require access to my own inner consciousness.

It is clear that Schütz, like Husserl, analyzes the social world strictly through the acts of consciousness of individual actors. References to social categories such as 'social environment', 'social relationships' and the like are made as if they can solely 'exist' through the eyes of individuals, the indivisible particles ('atoms') of social science. Also, the emergence of patterned conduct in society is seen in terms of a reduction of psychic complexity, of freeing the individual from the burden of having to choose each time anew how to behave in similar situations (see, following Schütz in this respect, Berger and Luckmann, 1966: 50-51). The collectivist moment, in Alexander's terms, is continually mediated by individual consciousnesses. A prime example of the problems the theory runs into is tied to the concept of institutionalization as advocated by Berger and Luckmann (1966). In an attempt to overcompensate for the freedom that action phenomenology bestows upon individual actors, these authors tend to attach positive value to institutionalization processes and the mutual integration of institutions. The opposite process, segregation, is valued rather negatively. But for the sociological observer, segregation of institutions is as much a phenomenon to be valued as is integration (Huysmans, 2001: 40). ${ }^{3}$ In short, due to the problems phenomenological sociology runs into because of its individualist propositions, it has a tendency to theoretically 'constrict' individual freedom too tightly in order to arrive at explaining the relatively orderly state most social systems find themselves in. The same, in my view, is true for symbolic interactionism. 


\section{Symbolic interactionism: Definition of the situation and joint action}

As a branch of sociology under this heading, symbolic interactionism has established itself mainly through the collection of essays by Herbert Blumer, entitled Symbolic Interactionism: Perspective and Method (1986). The most prominent essays are very programmatic in character, trying to convince the sociological observer that the first thing (s)he should do is get in touch with empirical reality $(33-34)$. Blumer draws heavily on work done in the Chicago School of sociology, in particular the work of George Herbert Mead. In Blumer's view, sociology has been too much concerned with describing the "large parts or aspects" of society - institutions, classes, organizations, corporations - in terms of "system principles". Human actors are seen as mere "media for the play and expression of the forces or mechanisms of the system". Instead, Blumer proposes to analyze what happens in social systems "in terms of the process of interpretation engaged in by the acting participants as they handle the situations at their respective positions in the organization" (57-58). The point of departure in his analysis is the definition of the situation. An acting individual needs to interpret his immediate environment, give meaning to selected objects in that environment, and construct a line of action before being able, indeed, to act. 'Joint or collective action', as this takes place in groups and organizations, relies on the same principle, even if the outcome of the fitting together of individual actions takes a direction unforeseen - if not unwanted - by either participant. What prevents joint action from getting out of hand is that participants have the capacity to reflect on their own actions in terms of how their counterparts interpret their behavior. They have developed an identity through repeatedly seeing their own actions through the eyes of others. By being able to evaluate one's own conduct from an outer position, both interactants can consciously control their actions and thereby arrive at a 'joint' action (cf. Mead, 1967: 73 f.; Blumer, 1986: 111).

This point of view about the 'nature of human action' is extended to social science methodology: "one has to get inside of the defining process of the actor in order to understand his action" (Blumer, 1986: 16). It is there, as I have laid out elsewhere (Huysmans, 2001: 42-43) that Blumer starts to confuse his theoretical and methodological positions in speaking about the nature and observation of 'joint actions'. First, he states that theoretically joint actions have a dynamic of their own, which is more than the sum total of multiple intertwining lines of action. So, in this stage of his analysis an organizational principle is put forward. Methodologically, the researcher who studies these joint actions is advised to seek contact with the interacting individuals in order to get a grasp on their respective definitions of the situation, which "yields a 
picture of the organized complex" of their joint action (Blumer, 1986: 58). Yet in a further, superfluous and erroneous step Blumer uses his methodological dictum as an argument against theorizing joint actions in terms of organizational or system principles (e.g., 59). This contradicts his own position. But there is no inherent contradiction in both theorizing joint actions as having a dynamic of their own and studying its emergence as such from the standpoints of the interacting individuals (Alexander and Giesen, 1987: 20; cf. Alexander, 1988). Multiple variants of the prisoner's dilemma, in which the amount of communication between the participants was varied, serve as a good case in point (cf. Sears, Freedman, and Peplau, 1985: 363-367). Like in phenomenological sociology, the idea that each action arises out of conscious consideration and sense making in each situation serves as a too restrictive argument against theorizing social collectivities as having a dynamic of their own, a dynamic which provides boundaries for individual meaninggiving. The point Blumer wants to make is that "the organization of a human society is the framework inside of which social action takes place and is not the determinant of that action. ... Such organization and changes in it are the product of the activity of acting units and not of 'forces' which leave such acting units out of account" (Blumer, 1986: 87). Here, Blumer uses an old rhetorical trick; painting a caricature of the opponent's (i. e., 'mainstream' sociology's) position in order to make your own position look more acceptable. In doing so, however, he ties symbolic interactionism too tightly to an anti-collectivist stance. Whenever he speaks of social collectivities (like families, schools, churches), those collectivities are seen as if they were individual 'acting units'. The actions of these 'units' are subject to the same situation definition and project-developing principles as are the actions of individuals.

Despite claiming that each collectivity in the last resort consists of acting individuals, Blumer fails to describe how a collectivity succeeds in demarcating itself from its social environment and recognizes itself as such. What is more, no distinction is made between an insider's and the outsiders' views on the identity of the group. A social group's definition of itself may be wholly different from the definition the outside world has of it (which is the case in individual identity formation as well). Since social attributions of identity are a main source of social conflict, this is a serious drawback of Blumer's theoretical position. A social scientist trying to account for diverging identity attributions does not find, in symbolic interactionism, the tools with which to construct a social theory that takes social mechanisms like these into account.

In stating that the social world and the meaning-giving processes taking place within it arise from individual consciousness exclusively, and have to be dealt with accordingly in a methodological sense, symbolic 
interactionism has foresaken the potential of Mead's pragmatic sociology. As Alexander (1988: 251-252) puts it: "Whereas Mead usually, though not always, spoke of meaning as the product of an unconscious attitudinal specification of general cultural patterns, (...) Blumer's individual is given incredible control over the meaning of his acts - a control contested only by the presence of other, equally separated selves." 4 How far the twain have drifted apart gets clear, perhaps surprisingly, when Blumer's work is confronted with systems theory.

\section{Systems theory: Human action as communicative attribution}

As I have tried to demonstrate in the previous sections, both phenomenological sociology and symbolic interactionism have analyzed human action and meaning-giving from the standpoint of individual 'subjective consciousness'. Either approach uses the 'last resort' argument to argue against collectivism, by on the one hand acknowledging that supra-individual categories like social structures and culture are important, but on the other hand maintaining that 'in the last resort' it is the individual who reproduces these categories in his actions. What is striking is that this has been the case whilst there was an inherent necessity in neither approach to take a polemicist attitude against collectivist positions. ${ }^{5}$

Nevertheless, the 'last resort' argument, convincing though it may seem, has unduly prevented action theory from paying attention to the analysis of social collectives. For it is one thing to say that every collective arises from the situation definitions of actors engaged in joint action, but quite another to arrive at descriptions, let alone explanations, for collective behavior. An important thing to recognize is that the objects an actor finds present in the situation in which he is about to act are contingent upon the actions of others. Therefore, his definition of the situation depends, to a considerable extent, upon the definitions of his co-actors in that situation. Blumer has tried to take this insecurity into account in his description of the 'joint action' (1986: 109-110). But instead of first analyzing the problem, he immediately proceeds to its solution by mentioning the social character of definition schemes and the self-reflexivity each actor brings to the situation. Talcott Parsons, whose ideas are strongly opposed by Blumer, instead stresses the inherent insecurity in interaction situations with his description of the double contingency problem:

The concept of interaction is the first-order step beyond the action concept itself toward formulating the concept of social system. (...) The crucial reference points for analyzing interaction are two: (1) that each actor is both acting agent and object of orientation both to him- 
self and to the others; and (2) that, as acting agent, he orients to himself and to others and, as object, has meaning to himself and to others, in all of the primary modes or aspects. (...) From these premises derives the fundamental proposition of the double contingency of interaction. Not only, as for isolated behaving units, animal or human, is a goal outcome contingent on successful cognition and manipulation of environmental objects by the actors, but since the most important objects involved in interaction act too, it is also contingent on their action or intervention in the course of events (Parsons, 1968: 436).

The inherent instability of the interaction situation leads in Parsons's eyes to the genesis of a social system. According to Luhmann ${ }^{6}$ (1995: 103 ff.; 1984: $148 \mathrm{ff}$.), however, the solution Parsons brings to bear on the double contingency problem - the presence of a normative orientation in both interactants with the mutual assumption of consensus already goes too far. Luhmann states that this normative orientation compensating for the mutual insecurity should not have been built, like Parsons did, into the concept of double contingency. Rather, Luhmann sees double contingency - "empty, closed, indeterminable self-reference" (Luhmann, 1995: 105; 1984: 151) as generating its own solution. In a situation of utter indeterminacy everything that happens has structuring value for the things to happen next. After an initial step by one of the interacting participants, every following step reduces complexity and thereby has determining value.

Combining concepts from Parsons's theory, general systems theory, Weber's categories of verstehende sociology, Husserlian phenomenology and Mead's pragmatism, Luhmann composes an abstract but at the same time illuminating perspective on the social world. The fundamental renewal Luhmann brings to social theory is that the double contingency problem, which arises in every situation in which two consciousnesses mutually intransparent 'black boxes', or psychic systems as Luhmann terms them - meet, leads to the building of a social system which is nothing more or less than communication, a self-referent network in which one communication follows another. Communication, in Luhmann's view, is not something that emerges from consciousness. People are not speaking their minds, translating their thoughts into words in what is called 'communicative action', like Habermas (1987) would have it (see Luhmann, 1995: 138; 1984: 192). Rather, both consciousness and communication should be seen as self-determining and self-referent wholes on the basis of meaning (Sinn). And subsequently, meaning is described as a phenomenon not exclusively restricted to the operations of consciousness. This is a decisive break with the phenomenological tradition of Husserl (Luhmann, 1995: 512; 1984: 93; cf. Kneer and Nas- 
sehi, 1993: 76) with far-reaching consequences. Meaning refers to the ever-present difference, not only in psychological experience but also in communication, between what is actually present and what is temporarily pushed into the background of attention. As meaning-based entities, psychic and social systems are mutually dependent upon each other; i. e., communication 'irritates' consciousness and vice versa. But they cannot interfere in each other's operations. It is precisely because of the mutual non-transparency of consciousnesses that communication comes about as a kind of 'compensation'.

It may not be clear from this brief sketch what is gained by such an abstract perspective on communication and consciousness. Nor may it be clear what it means for the conceptualization of human action, but I will turn to that now. In my view, Luhmann provides rather thoughtprovoking arguments, which should at least be reflected upon by action theorists. Already in 1971, in a discussion with Habermas, he argued that if 'meaning' is to be taken seriously as the basic concept of sociology, social (and psychic) systems cannot 'exist' outside of meaning (Luhmann, 1971a: 11-12). The boundaries of society are meaning-constituted boundaries and not of a physical or territorial nature. This is not to say that physical or territorial boundaries are irrelevant, but it does say that they are not 'part of' the system. Another implication is that a social system does not consist of human beings. Instead, as has already been said, social systems consist only of communications, and psychic systems consist of thoughts. In these networks of mutually referring thoughts and communications human beings are observed at most as entities in their environment. Meaning, as a concept, is to be defined prior to the subject concept, as the last necessarily presupposes the first (Luhmann, 1971b: 28). In action theory, where meaning is seen to spring from the consciousness of the subject, it is the other way around.

The implications of this for the conceptualization of human action can be sensed now. Action is to be seen as a meaningful attribution of conduct to a system, be it a social system (as in utterances like 'the police have taken precautionary measures' or 'my family has always been travelling a lot') or a psychic system ('I have made good progress in my work today'; 'you shouldn't have brought me flowers'). There is always a potential difference - and here a strong point of Luhmann's theory comes to the forefront - between self-attribution of actions by a system and the attribution(s) to that system by other systems. For instance, one can be pleased by one's performance ('I have done all I could to get the job finished today'), whereas others may be not ('Why is he leaving the office already, can't he work late for once?'). It is this difference in attribution that accounts for much of social dynamics. If one confronts it with the way phenomenology and symbolic interactionism conceive of 
human actions, it can be seen that judging human social action from each actor's intentions leaves out the double contingency inherent in interaction. One can easily surmise that the dissimilarity of perspectives can be socially important, and even decisive, in juridical communication. What counts most in terms of the social consequences is not whether the suspect actually intended to kill the victim, or has actually committed the crime, but rather whether the judge or the jury deems it proven beyond reasonable doubt that this was the case and passes the according judgement (see Schneider, 1994). I will return to this briefly in the next section.

What strikes one is that Luhmann distances himself from a long tradition in sociology from Weber via Parsons to various strands of modern action theory, which sees society as consisting of social actions, or human beings. Social systems are no longer seen as the products of human action. It is the other way around: "Sociality is not a special case of action; instead, action is constituted in social systems by means of communication and attribution as a reduction of complexity, as an indispensable self-simplification of the system" (Luhmann, 1995: 137; 1984: 191). That such a position will not be endorsed by symbolic interactionism is clear; ${ }^{7}$ it is, however, closer to Mead's thinking than many a symbolic interactionist is willing to concede (cf. Nassehi, 1993: 243).

\section{Conclusion: Action theory between individualism and collectivism}

From the previous sections, one might have gained the impression that a substitution of action theory by systems theory is advocated here. My point is, however, more subtle than that. The question that will be answered in this concluding section is: what can action theory gain by a reflection on the criticisms that Luhmann brings to bear? A general answer to that question would be: it can correct assumptions which have been too one-sidedly individualistic, and thereby draw on the useful contributions of phenomenology (Schütz) and pragmatism (Mead) to social theory without incorporating the theoretical flaws added by either's successors.

Luhmann makes a very solid point in criticizing subjectivist theories, which start with the subject and from there try to get a grasp of what ties these subjects together. 'Intersubjectivity', in his view, is a formula which is introduced the moment one tries to stick to the subjectivity of consciousness and introduces something which cannot be conceived of in this theory. The 'inter' contradicts the 'subject', or rather each subject has its own intersubjectivity (Luhmann, 1986a: 42; see also 1995: 81, 146 [1984: 120, 202]; 1997: 1027-1032). If one allows communication to be conceived of as a system organizing itself outside of consciousness, this 
does not mean, as is often claimed (for instance by Blumer), that the acting subject is determined from the outside, by the system. Even the opposite can be said to be the case; i. e., because human beings are seen not as the building blocks of society, but as objects in the environment of society, they have more freedom in their actions, particularly more freedom to act irrationally and immorally (cf. 1995: 212-213; 1984: 289). Communication, after all, cannot take part in the operations of consciousness, and thus can never tell consciousnesses what to think. Communication, on the other hand, is more free to develop its own dynamics. This is more in line with the common knowledge that once a conflict between two or more people has started, it is very hard to control its course. Luhmann's elaboration on social conflict, in my view, serves as a case in point of the productivity of this perspective (1995, 1984, chapter 9).

Furthermore, the point Luhmann makes about the Sinngrenzen (meaning-constituted boundaries) of consciousness and communication should be taken seriously both in action theory and in its methodology. Whereas in action theory the actual performance of the preconceived act in the outer world tends to occupy a central place in the theory and these acts are analyzed accordingly in research (as 'physical entities' so to speak), this view is contested in systems theory. Everything that takes place in social systems (in communication) does so in the form of meaning. This is not to say that meaning would never refer to actual 'things out there'. Of course, we do move our bodies when we go shopping, and we feel our vocal cords as we speak. There is a world out there, but for social and psychic systems it only 'exists' in meaningful reference. An implication of this for empirical research is that actions should be analyzed according to the theoretical scheme; i. e., as communicative or conscious attributions. In the past decade, a discussion has been going on in German sociology about the methodological implications of systems theoretical thought which reconceptualizes Weber's 'Sinnverstehen' and applies it to the analysis of communication protocols (see Kneer and Nassehi, 1991; Nassehi, 1997; Schneider, 1992, 1994, 1996, 1997; Sutter, 1999; cf. Luhmann, 1986b) with illuminating results. The consciousness of the actor is no longer seen as the primary or single source of meaning attribution. The meaning of an action is constituted instead as a synthesis of self- and foreign attribution, and the potential difference between the two can be made productive (Schneider, 1994: 267).

Thus, action theoretical approaches in mass communications research (see Anderson and Meyer, 1988; Charlton and Neumann, 1986; Renckstorf, 1989, 1994; Renckstorf, McQuail, and Jankowski, 1996; Renckstorf and Wester, 1992; Schoening and Anderson, 1995) could develop a 
more detailed perspective on the position of the mass media as a societal subsystem (Luhmann, 1996). Describing the mass media as (a) social system(s) is one thing (see for instance Renckstorf, 1994: 38), it is quite another to explain their functioning from the situation definitions of the actors involved, as action theory would have it. A more productive position would be, in my view, to conceive of the mass media as a societal subsystem, without downplaying the contribution of individual actors to its functioning (see Scholl and Weischenberg, 1998; Huysmans, 2002). This enables one to study the media supply and demand sides in one overarching theoretical framework, which allows for human consciousness to observe reality, but for the mass media as a social system as well. As was the case in the study of juridical communication, the dissimilarity of perspectives between the media themselves, between media and their users, and between media users themselves, could be rendered productive in a more 'holistic' approach (see Früh 1991) to media use research.

\section{Notes}

1. The English translation is entitled The phenomenology of the social world (1967).

2. A problematic translation, since the distinction between Sinn and Bedeutung in German is blurred. A more apt translation, in my view, would be sense. I will use meaning nevertheless in conformity to common practice in social science.

3. Another example of the underdeterminedness of social categories in Schütz' work is the concept of 'social time'. The concept pops up every now and then (for example in Schütz and Luckmann, 1979, 1984) without being clarified. In Schütz (1982: 224) a conceptualization is announced, but the manuscript ends before the promise is redeemed. Nassehi (1993) concludes that social structures, and the social time category in particular, remain 'underdefined' in Schütz (see also Huysmans, 2001: 71-75).

4. The same point of criticism on Blumer's "misinterpretation of Mead" (Alexander, 1988, p. 253) is made by Hans Joas in his dissertation Praktische Intersubjektivität (Joas, 1989: 12), who attributes the 'enormous divergences' between symbolic interactionism and Mead's work to 'an extremely fragmentary reception' of Mead's work by Blumer.

5. "When we look at the most sophisticated and most successful strands of phenomenology and interactionism, we see that they were not intended to be epistemological and ontological confrontations with theories that posit supraindividual order; rather, they were intended to give greater urgency to an empirical aspect of order that has been neglected by most such collectivist theories, at least post-Hegel: the relationship between the prior, supraindividual order and the moment-to-moment unfolding of real historical time. The relations between order and contingency, these traditions have argued, can be illuminated only by a more detailed empirical understanding of the processes of individual consciousness" (Alexander, 1988: 253-254).

6. Luhmann's Soziale Systeme, Grundriß einer allgemeinen Theorie (1984) will be cited here both in the original German version and in the English translation (1995). 
7. “'Symbolic interactionism' (...) builds a contingently acting alter ego into the ego and sees, quite correctly, the process of mediation as the use of symbols. But it treats the problem only on one side of the interaction, assuming that all is the same on the other. It treats, so to speak, only half of double contingency and thereby remains a theory of action. Social systems emerge, however, through (and only through) the fact that both partners experience double contingency and that the indeterminability of such a situation for both partners in any activity that then takes place possesses significance for the formation of structures. This cannot be grasped via the basic concept of action" (Luhmann, 1995: 108; 1984: 154).

\section{References}

Alexander, J. C. (1988). Action and its environments. Toward a new synthesis. New York: Columbia University Press.

Alexander, J. C. and Giesen, B. (1987). From reduction to linkage: The long view of the micro-macro debate. In J. C. Alexander, B. Giesen, R. Münch, and N. J. Smelser (Eds.), The micro-macro link (pp. 1-42). Berkeley, CA: University of California Press.

Anderson, J. A. and Meyer, T. P. (1988). Mediated communication. A social action perspective. Newbury Park, CA: Sage.

Berger, P. and Luckmann, T. (1966). The social construction of reality. A treatise in the sociology of knowledge. New York: Doubleday.

Blumer, H. (1986). Symbolic interactionism. Perspective and method. Chicago, IL: Chicago University Press [orig.: 1969].

Charlton, M. and Neumann, K. (1986). Medienkonsum und Lebensbewältigung in der Familie. Methode und Ergebnisse der strukturanalytischen Rezeptionsforschung mit fünf Falldarstellungen. München-Weinheim: Psychologie Verlags Union.

Coleman, J. S. (1990). Foundations of social theory. Cambridge, MA: Belknap.

Früh, W. (1991). Medienwirkungen: Das dynamisch-transaktionale Modell. Theorie und empirische Forschung. Opladen: Westdeutscher Verlag.

Habermas, J. (1987). Theorie des kommunikativen Handelns (2 Bände). Frankfurt am Main: Suhrkamp.

Huysmans, F. (2001). Mediagebruik en de temporele organisatie van het dagelijks leven in huishoudens. Nijmegen: Author.

Huysmans, F. (2002). Mediennutzung und die zeitliche Organisation des Alltags in Haushalten. In A. Scholl (Ed.), Systemtheorie und Konstruktivismus in der Kommunikationswissenschaft (pp. 247-260). Konstanz: UVK.

Joas, H. (1989). Praktische Intersubjektivität. Die Entwicklung des Werkes von G. H. Mead. Frankfurt am Main: Suhrkamp.

Kneer, G. and Nassehi, A. (1991). Verstehen des Verstehens. Eine systemtheoretische Revision der Hermeneutik. Zeitschrift für Soziologie, 20 (5), 341-356.

Kneer, G. and Nassehi, A. (1993). Niklas Luhmanns Theorie sozialer Systeme. Eine Einführung. München: Fink.

Luhmann, N. (1971a). Moderne Systemtheorien als Form gesamtgesellschaftlicher Analyse. In J. Habermas and N. Luhmann (Eds.), Theorie der Gesellschaft oder Sozialtechnologie - Was leistet die Systemforschung? (pp. 7-24). Frankfurt am Main: Suhrkamp.

Luhmann, N. (1971b). Sinn als Grundbegriff der Soziologie. In J. Habermas and N. Luhmann (Eds.), Theorie der Gesellschaft oder Sozialtechnologie - Was leistet die Systemforschung? (pp. 25-100). Frankfurt am Main: Suhrkamp.

Luhmann, N. (1984). Soziale Systeme. Grundriß einer allgemeinen Theorie. Frankfurt am Main: Suhrkamp. 
Luhmann, N. (1986a). Intersubjektivität oder Kommunikation: Unterschiedliche Ausgangspunkte soziologischer Theoriebildung. Archivio di Filosofia, 54 (1-3), $41-60$.

Luhmann, N. (1986b). Systeme verstehen Systeme. In N. Luhmann and K. E. Schorr (Eds.), Zwischen Intransparenz und Verstehen. Fragen an die Pädagogik (pp. 72117). Frankfurt am Main: Suhrkamp.

Luhmann, N. (1995). Social systems. Stanford, CA: Stanford University Press.

Luhmann, N. (1996). Die Realität der Massenmedien (2., erw. Aufl.). Opladen: Westdeutscher Verlag.

Luhmann, N. (1997). Die Gesellschaft der Gesellschaft. Frankfurt am Main: Suhrkamp.

Mead, G. H. (1967). Mind, self, and society from the standpoint of a social behaviorist. Chicago, IL: University of Chicago Press.

Nassehi, A. (1993). Die Zeit der Gesellschaft. Auf dem Weg zu einer soziologischen Theorie der Zeit. Opladen: Westdeutscher Verlag.

Nassehi, A. (1997). Kommunikation verstehen. Einige Überlegungen zur empirischen Anwendbarkeit einer systemtheoretisch informierten Hermeneutik. In T. Sutter (Ed.), Beobachtung verstehen, Verstehen beobachten. Perspektiven einer konstruktivistischen Hermeneutik (pp. 134-163). Opladen: Westdeutscher Verlag.

Parsons, T. (1968). Social interaction. In D. L. Sills (Ed.), International encyclopedia of the social sciences, Vol. 7 (pp. 429-441). New York: Macmillan/Free Press.

Renckstorf, K. (1989). Mediennutzung als soziales Handeln: Zur Entwicklung einer handlungstheoretischen Perspektive der empirischen (Massen)Kommunikationsforschung. In M. Kaase and W. Schulz (Eds.), Massenkommunikation: Theorien, Methoden, Befunde. Sonderheft 30/1989 der Kölner Zeitschrift für Soziologie und Sozialpsychologie (pp. 314-336). Opladen: Westdeutscher Verlag.

Renckstorf, K. (1994). Mediagebruik als sociaal handelen. Een handelingstheoretische benadering voor communicatiewetenschappelijk onderzoek. Nijmegen: Instituut voor Toegepaste Sociale Wetenschappen (ITS).

Renckstorf, K. and Wester, F. (1992). Die handlungstheoretische Perspektive empirischer (Massen-) Kommunikationsforschung: Theoretischer Ansatz, methodische Implikationen und forschungspraktische Konsequenzen. Communications, 17 (2), $177-196$.

Renckstorf, K., McQuail, D., and Jankowski, N. (Eds., 1996). Media Use As Social Action. A European Approach to Audience Studies. London: Libbey.

Schneider, W. L. (1992). Hermeneutik sozialer Systeme. Konvergenzen zwischen Systemtheorie und philosophischer Hermeneutik. Zeitschrift für Soziologie, 21 (6), $420-439$.

Schneider, W. L. (1994). Die Beobachtung von Kommunikation. Zur kommunikativen Konstruktion sozialen Handelns. Opladen: Westdeutscher Verlag.

Schneider, W. L. (1996). Die Komplementarität von Sprechakttheorie und systemtheoretischer Kommunikationstheorie. Ein hermeneutischer Beitrag zur Methodologie von Theorievergleichen. Zeitschrift für Soziologie, 25 (4), 263-277.

Schneider, W. L. (1997). Die Analyse von Struktursicherungsoperationen als Kooperationsfeld von Konversationsanalyse, objektiver Hermeneutik und Systemtheorie. In T. Sutter (Ed.), Beobachtung verstehen, Verstehen beobachten. Perspektiven einer konstruktivistischen Hermeneutik (pp. 164-227). Opladen: Westdeutscher Verlag.

Schoening, G. T. and Anderson, J. A. (1995). Social action media studies: Foundational arguments and common premises. Communication Theory, 5 (2), 93-116.

Scholl, A. and Weischenberg, S. (1998). Journalismus in der Gesellschaft. Theorie, Methodologie und Empirie. Opladen: Westdeutscher Verlag.

Schütz, A. (1974). Der sinnhafte Aufbau der sozialen Welt. Eine Einleitung in die verstehende Soziologie. Frankfurt am Main: Suhrkamp. 
Schütz, A. (1982). Das Problem der Relevanz. Frankfurt am Main: Suhrkamp.

Schütz, A. and Luckmann, T. (1979). Strukturen der Lebenswelt, Band 1. Frankfurt am Main: Suhrkamp.

Schütz, A. and Luckmann, T. (1984). Strukturen der Lebenswelt, Band 2. Frankfurt am Main: Suhrkamp.

Sears, D. O., Freedman, J. L., and Peplau, L. A. (1985). Social Psychology (5 ${ }^{\text {th }}$ Ed.). Cliffs, NJ: Prentice-Hall.

Sutter, T. (1999). Systeme und Subjektstrukturen. Zur Konstitutionstheorie des interaktionistischen Konstruktivismus. Opladen/Wiesbaden: Westdeutscher Verlag.

Weber, M. (1984). Soziologische Grundbegriffe. 6., erneut durchgesehene Auflage, mit einer Einführung von Johannes Winckelmann. Tübingen: Siebeck. 